\title{
Erratum to: Direct somatic embryogenesis of Agave fourcroydes Lem. through thin cell layer culture
}

\author{
Kelly M. Monja-Mio ${ }^{1} \cdot$ Manuel L. Robert $^{1}$
}

Published online: 24 December 2015

(C) The Society for In Vitro Biology 2015

Erratum to: In Vitro Cell Dev Biol Plant, Vol. 49 No. 5 pp.

541-549

DOI 10.1007/s11627-013-9535-7

"Teixeira da Silva" was incorrectly spelled as "Texeira da Silva" in 3 citations and 1 reference.

The first and second citations are on page 542, second paragraph, and the 3 rd citation on page 548 , first paragraph. The reference is located on page 549 , second reference from the end.

The online version of the original article can be found at http://dx.doi.org/ 10.1007/s11627-013-9535-7.

Kelly M. Monja-Mio

kellymabel@hotmail.com

1 Centro de Investigación Científica de Yucatán, Unidad de Biotecnología, A.C. Calle $43 \mathrm{~N}^{\circ} 130$, Chuburná de Hidalgo, Mérida, Yucatán 97200, México 